\title{
Cylinder Device
}

National Cancer Institute

\section{Source}

National Cancer Institute. Cylinder Device. NCI Thesaurus. Code C49906.

Any part of a device that resembles an enclosed tube; a cylindrical container for the storage of gases and fluids. 